\title{
Morphological and Ecophysiological Indicators for Coriander Under Irrigation Depths and Nitrogen Levels
}

\author{
Fábio Teixeira Delazari ${ }^{1}$, Mariane Gonçalves Ferreira Copati ${ }^{1}$, Gustavo Henrique da Silva ${ }^{2}$, \\ Ronaldo Silva Gomes ${ }^{1}$, Derly José Henriques da Silva ${ }^{1} \&$ Carlos Nick ${ }^{1}$ \\ ${ }^{1}$ Plant Science Department, Federal University of Viçosa, University Campus, Viçosa, MG, Brazil \\ ${ }^{2}$ Agricultural Engineering Departament, Federal University of Viçosa, University Campus, Viçosa, MG, Brazil \\ Correspondence: Mariane Gonçalves Ferreira Copati, Plant Science Department, Federal University of Viçosa, \\ University Campus, 36570-900 Viçosa, MG, Brazil. Tel: 55-313-899-1133. E-mail: \\ marianegonferreira@gmail.com
}

Received: November 20, 2018

Accepted: December 24, 2018

Online Published: February 15, 2019

doi:10.5539/jas.v11n3p549

URL: https://doi.org/10.5539/jas.v11n3p549

\begin{abstract}
Nitrogen fertilization and supplying of water are crucial factors for quality and quantity produces of coriander. The objective of this study was to evaluate morphological and ecophysiological characteristics for coriander under five irrigation depths and two doses of nitrogen $(\mathrm{N})$. Experimental layout was completely randomized design in a split plot scheme with five replications. The irrigation depths (plot) was 25, 50, 75, 100 and 125\% of crop evapotranspiration $\left(\mathrm{ET}_{\mathrm{c}}\right.$ ). The doses of $\mathrm{N}$ (subplot) corresponded to 35 and $70 \mathrm{~kg} \mathrm{ha}^{-1}$. The cultivation of coriander ("Vedete") was in a protected environment. The ratio between the aerial part and roots linearly increased with the increment of the irrigation depths and was highest under $70 \mathrm{~kg} \mathrm{ha}^{-1}$ of nitrogen. The leaf area index linearly increased with the increment of the irrigation depths at both doses of $\mathrm{N}$. The leaf index of chlorophyll "a" was highest under irrigation depths of 87 and $75 \%$ of $\mathrm{ET}_{\mathrm{c}}$ for 35 and $70 \mathrm{~kg} \mathrm{ha}^{-1}$ of N, respectively. The leaf index of chlorophyll "b" decrease linearly with the increase of irrigation depths in both doses of $\mathrm{N}$. The nitrogen use efficiency was maximized with high soil moisture conditions. The water use efficiency decreases linearly with increasing of irrigation depth. The best irrigation depth and nitrogen dose obtained in this study was $125 \%$ of ETc and $70 \mathrm{~kg} / \mathrm{ha}$. The leaf index of chlorophyll "a" and "b" are important indicators of hydric stress. The leaf index of chlorophyll "b" are negatively correlated with leaf area index. N supply increase the water use efficiency.
\end{abstract}

Keywords: Coriandrum sativum L., irrigation management, nitrogen fertilization, water economy

\section{Introduction}

The coriander (Coriandrum sativum L.), a member of Apiaceae family, is an important herbaceous-horticultural annual spices and medicinal plant. Original from the Mediterranean, it is cultivated in the entire world due culinary and industrial uses mainly by strong and typical aroma. For this plant, leafs are used in many regional dishes and seeds are natural sources of essential oils such as limonene, $\beta$-cymene, linalool, $\alpha$-Terpineol, nerol and geraniol (Hassan \& Ali, 2013; Hani et al., 2015). Furthermore, the seeds compose several condiments and cosmetics (Diwan et al., 2018).

Nutrients fertilization, mainly nitrogen $(\mathrm{N})$, has great importance in quality and quantity of coriander produce (Diwan et al., 2018; Angeli et al., 2016). N is necessary for protein synthesis and the $\mathrm{N}$ leaf status is frequently measured by chlorophyll contents through indirect methods as leaf chlorophyll index (Andrade et al., 2017).

The response of coriander to nitrogen fertilization depends primarily of soil water conditions (Bhunia et al., 2009; Carruba, 2009). Deficit irrigation in coriander reduces leafs (Drunasky \& Struve, 2005) and seeds (Kumar et al., 2008) production and the critical crop phenology are flowering (Kumar, 2008). Water requirement depends predominantly on the edaphoclimatic conditions and crop phenology. However, was demonstrate that coriander growing are maximized at higher (> 100\%) irrigation depths (Angeli et al., 2016; Hassan \& Ali, 2013).

The interaction of irrigation depth and nitrogen fertilization is not clear for cultivation of coriander. However, the objective was to evaluate morphological and ecophysiological characteristics for coriander under five irrigation depths and two doses of nitrogen. 


\section{Method}

\subsection{Experimental Conditions}

Coriander ("Vedete") was cultivated under five irrigation depths and two doses of nitrogen during September and October 2014 at Experimental Horticulture of the Department of Plant Science, in the Federal University of Viçosa (UFV), in Viçosa, Brazil $\left(20^{\circ} 45^{\prime} \mathrm{S}, 42^{\circ} 52^{\prime} \mathrm{W}\right.$ and $648 \mathrm{~m}$ ). The cultivation was in a protected environment $(7.0 \times 24.0 \mathrm{~m})$ with anti-aphids screen on the sides and a transparent plastic cover $(40 \mu \mathrm{m})$. The soil was Argissol with physical, hydric and chemical characteristics show in Table 1.

Table 1. Chemical, physical and soil water characteristics in the experimental area Viçosa, Minas Gerais, Brazil, 2014

\begin{tabular}{ll|ll}
\hline Depth $(\mathrm{cm})$ & $0-20$ & Depth $(\mathrm{cm})$ & $0-20$ \\
\hline $\mathrm{pH} \mathrm{in} \mathrm{H}_{2} \mathrm{O}$ & 6.30 & $\mathrm{~V}(\%)$ & 81.00 \\
$\mathrm{P}\left(\mathrm{mg} \mathrm{dm}^{-3}\right)$ & 126.10 & $\mathrm{MO}(\mathrm{dag} \mathrm{kg})^{-1}$ & 3.10 \\
$\mathrm{~K}\left(\mathrm{mg} \mathrm{dm}^{-3}\right)$ & 189.00 & P-rem $\left(\mathrm{mg} \mathrm{L}^{-1}\right)$ & 34.30 \\
$\mathrm{Ca}\left(\mathrm{cmol}_{\mathrm{c}} \mathrm{dm}^{-3}\right)$ & 7.30 & $\theta_{\mathrm{FC}}\left(\mathrm{m}^{3} \mathrm{~m}^{-3}\right)^{1}$ & 0.40 \\
$\mathrm{Mg}\left(\mathrm{cmol}_{\mathrm{c}} \mathrm{dm}^{-3}\right)$ & 1.50 & $\theta_{\mathrm{WP}}\left(\mathrm{m}^{3} \mathrm{~m}^{-3}\right)^{2}$ & 0.25 \\
$\mathrm{Al}\left(\mathrm{cmol}_{\mathrm{c}} \mathrm{dm}^{-3}\right)$ & 0.00 & Clay $\left(\mathrm{dag} \mathrm{kg}^{-1}\right)^{3}$ & 33.0 \\
$\mathrm{H}+\mathrm{Al}\left(\mathrm{cmol}_{\mathrm{c}} \mathrm{dm}^{-3}\right)$ & 2.15 & Silt $(\operatorname{dag~kg})^{-1}$ & 19.0 \\
$\mathrm{~T}\left(\mathrm{cmol}_{\mathrm{c}} \mathrm{dm}^{-3}\right)$ & 11.40 & Sand $\left(\mathrm{dag} \mathrm{kg}^{-1}\right)^{3}$ & 48.0 \\
\hline
\end{tabular}

Note. ${ }^{1}$ Field capacity. ${ }^{2}$ Permanent wilting point. Textural classification according to the Brazilian Society of Soil Sciences (Santos et al., 2005). P, K, Fe, $\mathrm{Zn}, \mathrm{Mn}$ and $\mathrm{Cu}$ available, extracted by Mehlich. $\mathrm{Ca}, \mathrm{Mg}$ and exchangeable Al extracted with $\mathrm{KCl} 1.0 \mathrm{~mol} \mathrm{~L}^{-1}$. Potential acidity at $7.0 \mathrm{pH}$, extracted with calcium acetate 1.0 $\mathrm{mol} \mathrm{L}{ }^{-1}$. B extracted with hot water.

The sowing was performed on 19 September 2014 in polyethylene trays of 200 cells (three seeds for cell). The substrate used was Carolina ${ }^{\circledR}$, Standard II, with electrical conductivity of $1.5 \mathrm{mS} \mathrm{cm}{ }^{-1}$. The transplanting was carried out fifteen days after sowing, when the seedlings had the first pair of definitive leaves. The spacing adopted was $0.20 \times 0.05 \mathrm{~m}$ in beds with $1.2 \mathrm{~m}$ wide and $3.0 \mathrm{~m}$ long. Each experimental unit corresponded to a total area of $0.60 \mathrm{~m}^{2}$, and the useful area considered was $0.24 \mathrm{~m}^{2}$.

It was applied $133 \mathrm{~kg} / \mathrm{ha}$ of monoammonium phosphate (MAP) (45\% P2O5 and $9 \% \mathrm{~N})$ at transplanting. The nitrogen source was urea and was it applied in two covering fertilization, the first at 10 and the second at 20 days after transplanting. There was not need to correct the soil acidity.

\subsection{Experimental Design}

Experiment layout was completely randomized design in a split plot scheme with five replications. The irrigation depths corresponding to $25,50,75,100$ and $125 \%$ of the crop evapotranspiration $\left(\mathrm{ET}_{\mathrm{c}}\right)$ were evaluated in the plots. The doses of $35\left(\mathrm{~N}_{1}\right)$ and $70\left(\mathrm{~N}_{2}\right) \mathrm{kg} \mathrm{ha}^{-1}$ of nitrogen (Oliveira et al., 2003) were evaluated in the subplots.

$\mathrm{The}_{\mathrm{ET}}$ was estimated through climatic variables (Allen et al., 1998, Angeli et al., 2016; Freitas et al., 2017). The initial, medium and end $\mathrm{K}_{\mathrm{cb}}$ were $0.15,1.15$ and 0.70, respectively (Allen et al., 1998). The period of the initial, intermediate, middle and final crop phenology stages were 70, 186, 310 and 360 degree days, respectively, considering as basal temperature of $12{ }^{\circ} \mathrm{C}$. The equation is as follows:

$$
\mathrm{ET}_{\mathrm{c}}=\mathrm{ET}_{0} \times\left(\mathrm{K}_{\mathrm{cb}} \cdot \mathrm{K}_{\mathrm{s}}+\mathrm{K}_{\mathrm{e}}\right)
$$

Where, $\mathrm{ET}_{\mathrm{c}}$ is coriander evapotranspiration $\left(\mathrm{mm} \mathrm{d}^{-1}\right), \mathrm{ET}_{0}$ is reference evapotranspiration $\left(\mathrm{mm} \mathrm{d}^{-1}\right), \mathrm{K}_{\mathrm{cb}}$ is coriander basal coefficient, $\mathrm{K}_{\mathrm{s}}$ is stress coefficient and $\mathrm{K}_{\mathrm{e}}$ is water coefficient of evaporation in soil.

Five days after the transplanting was implemented the irrigation depths. It was used drip irrigation with a flow rate of $1.13 \mathrm{~L} \mathrm{~h}^{-1}$, operation pressure of $80 \mathrm{kPa}$ and Christiansen uniformity coefficient of $97.9 \%$. The spacing between emitters was $0.30 \times 0.20 \mathrm{~cm}$, resulting in an application intensity of $14.07 \mathrm{~mm} \mathrm{~h}^{-1}$.

\subsection{Measurements}

The aerial part (leafs and stem) and roots were collected from five plants when they achieved a commercial size (height of 0.2 to $0.3 \mathrm{~m}$ ). Both parts were dried at $70^{\circ} \mathrm{C}$ to constant mass. Posteriorly was obtain the ratio $\mathrm{AP} / \mathrm{R}$, reason between dry masses of the aerial part (AP) and roots (R). 
The leaf area was determined with scanner (LI-COR BIOSCIENCE., model LAI 3001, Nebraska, USA). Subsequently, the leaf area index (LAI) was calculated by the reason between the leaf area and the surface soil area occupied by the plant.

Leaf index chlorophyll "a" (LICa) and "b" (LICb) were estimated by a portable electronic chlorophyll measurer (FALKER, model CFL 1030, Porto Alegre, Brazil). The leaf index of chlorophyll ranged from 0.0 to 100.0 with a resolution of 0.1. It was realized three measurements in each five healthy plants for experimental unit.

Nitrogen use efficiency (NUE) and water use efficiency (WUE) were obtained by the Equation 2 and 3.

$$
\begin{aligned}
\mathrm{NUE} & =\frac{\mathrm{AP}}{\mathrm{N}} \\
\mathrm{WUE} & =\frac{\mathrm{AP}}{\mathrm{VW}}
\end{aligned}
$$

Where, NUE is nitrogen use efficiency $\left(\mathrm{kg} \mathrm{kg}^{-1}\right)$, WUE is water use efficiency $\left(\mathrm{kg} \mathrm{m}^{-3}\right)$, AP is dry mass of aerial part $\left(\mathrm{kg} \mathrm{ha}^{-1}\right), \mathrm{N}$ is dose of nitrogen $\left(\mathrm{kg} \mathrm{ha}^{-1}\right)$ and VW is applied volume of water $\left(\mathrm{m}^{-3}\right)$.

\subsection{Statistical Analysis}

The values of the response variables were analyzed by regression analysis. For this, the models were selected based on the significance of their terms, in the $t$ test at the probability of $0.01,0.05$ and 0.10 , in the coefficient of determination and on the agronomic meaning of the variable.

\subsection{Climatic Conditions}

The data of air temperature, air relative humidity, solar radiation and evapotranspiration were obtained from a meteorological station installed in the experiment.

The ranged of air temperature was from 22.6 to $26.3{ }^{\circ} \mathrm{C}$, air relative humidity was from 75 to $89 \%$, the solar radiation was from 53 to $162 \mathrm{~W} \mathrm{~m}^{-1}$ and the reference evapotranspiration $\left(\mathrm{ET}_{0}\right)$ was from 1.2 to $3.3 \mathrm{~mm} \mathrm{~d}^{-1}$ (Figures 1A and 1B).

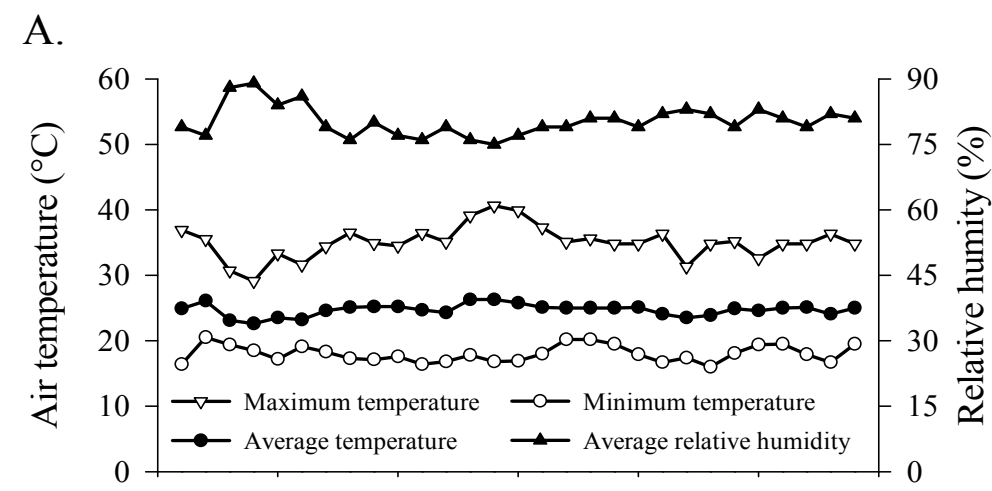

B.

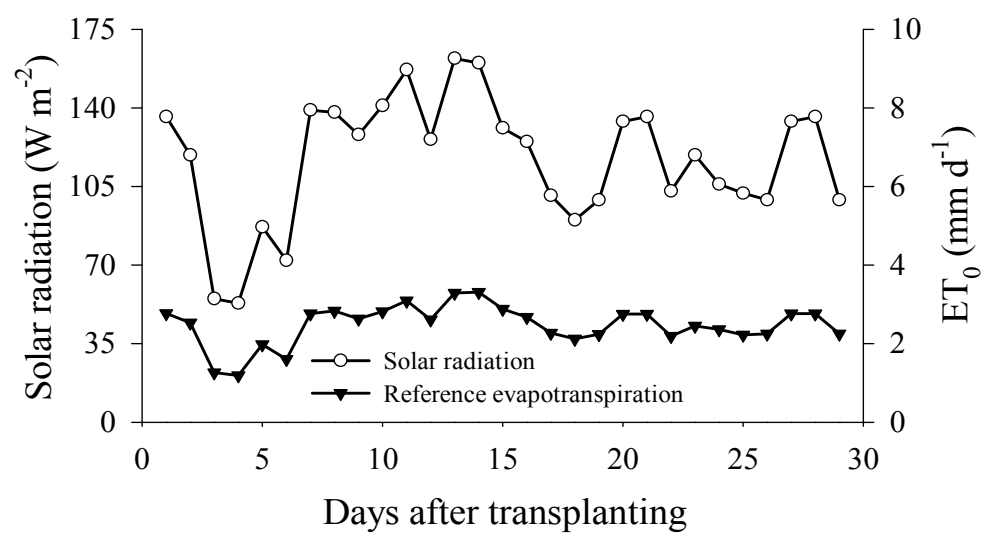

Figure 1. Maximum, average and minimum temperature; air relative humidity (A). Solar radiation and reference evapotranspiration (ET0) (B), during the experiment 
The Figure 2 shows the water soil balance in the irrigation depth of $100 \%$ of $\mathrm{ET}_{\mathrm{c}}$. The soil moisture remained in the interval comprised between the field capacity and the safety humidity during the experimental period.

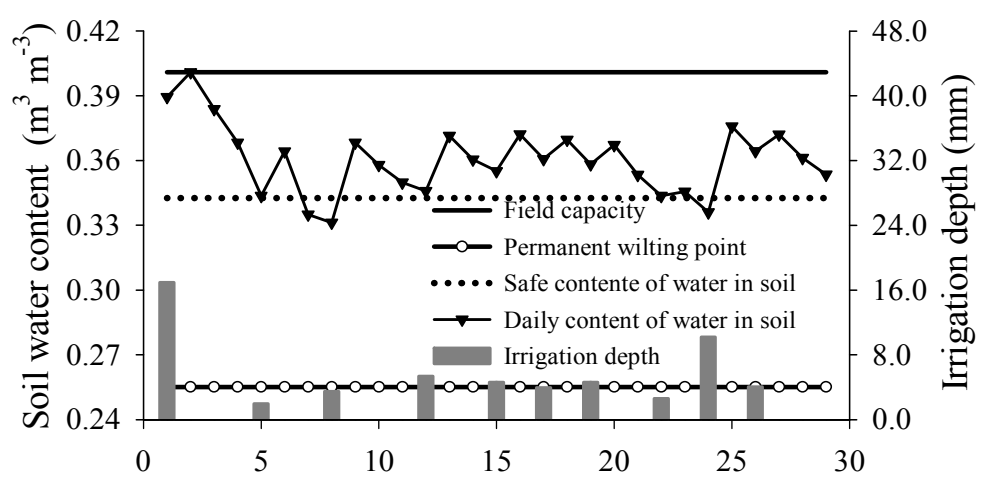

Days after transplanting

Figure 2. Walter balance for the irrigation depths corresponding to $100 \%$ of the $\mathrm{ET}_{\mathrm{c}}$ during the experimental period

\section{Results}

\subsection{The Effect of the Irrigation Depths and Nitrogen Fertilization on Plant Morphology}

The ratio, between dry mass of the aerial part and roots, AP/R linearly increased with the increment of the irrigation depths. The ratio AP/R was 10.9 and $14.9 \mathrm{~g} \mathrm{~g}^{-1}$ for $\mathrm{N}_{1}$ and $\mathrm{N}_{2}$, respectively in irrigation depth of $125 \%$ of $\mathrm{ET}_{\mathrm{c}}$. Moreover, this increasing was more expressive under the higher dose of N (Figure 3A).

A.

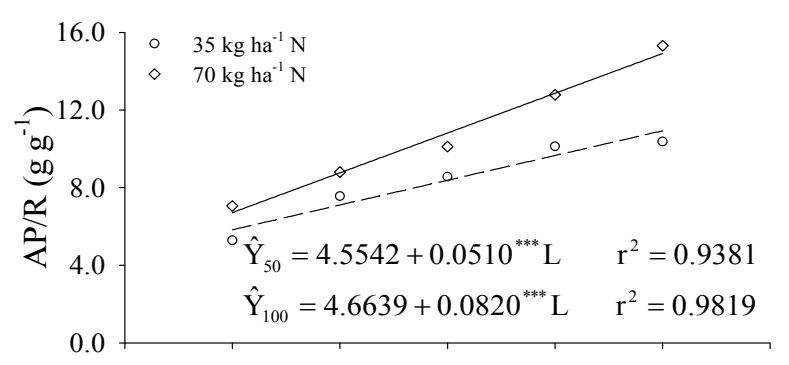

B.

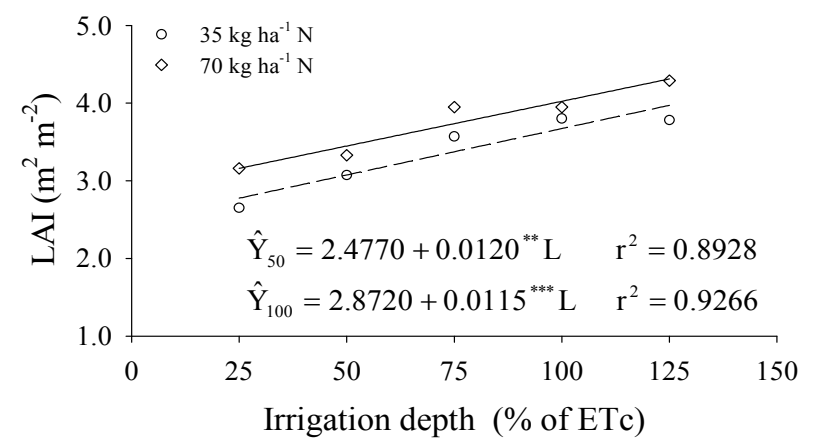

Figure 3. Ratio between dry mass of the aerial part and roots (A) and leaf area index (B) as a function of irrigation depths $\left(\%\right.$ of $\left.\mathrm{ET}_{\mathrm{c}}\right)$ and doses of nitrogen $\left(\mathrm{kg} \mathrm{ha}^{-1}\right) . * * *, * *$ significant at 0.01 and 0.05 by the test $\mathrm{t}$ of Student, respectively

The leaf area index (LAI) linearly increased with the increment of the irrigation depths at both doses of $\mathrm{N}$ (Figure 3B). The LAI was 4.0 and $4.2 \mathrm{~m}^{2} \mathrm{~m}^{-2}$ for $\mathrm{N}_{1}$ and $\mathrm{N}_{2}$, respectively in irrigation depth of $125 \%$ of $\mathrm{ET}_{\mathrm{c}}$. 


\subsection{The Effect of the Irrigation Depths on Chlorophyll $a$ and $b$}

The leaf index of chlorophyll "a" (LICa) was highest under irrigation depths of 87 and $75 \%$ of $\mathrm{ET}_{\mathrm{c}}$ for $\mathrm{N}_{1}(35.2)$ and $\mathrm{N}_{2}$ (36.4), respectively (Figure 4A).

A.

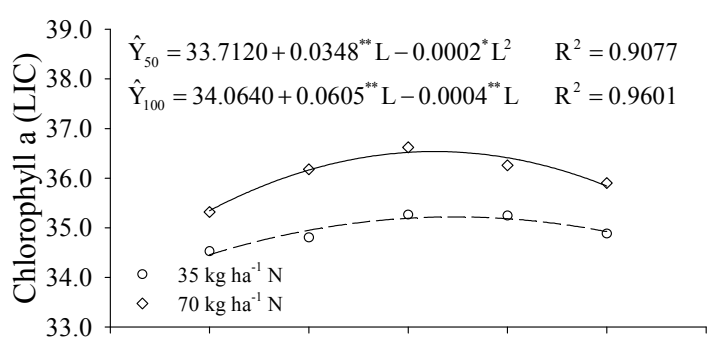

B.

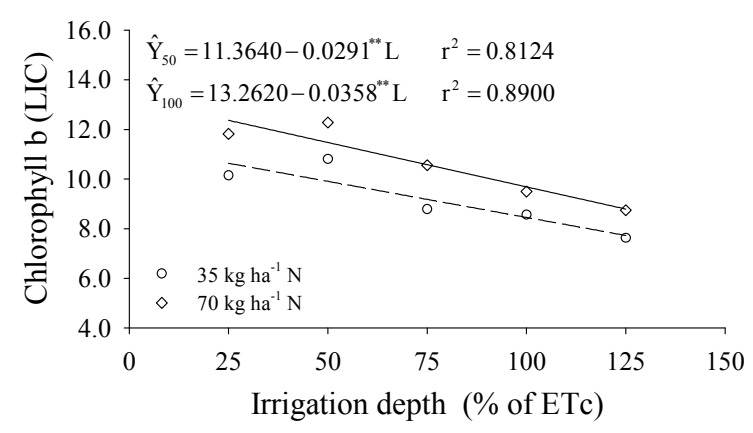

Figure 4. Leaf index of chlorophyll "a" (A) and "b" (B) as a function of irrigation depths (\% of $\left.\mathrm{ET}_{\mathrm{c}}\right)$ and doses of nitrogen $\left(\mathrm{kg} \mathrm{ha}^{-1}\right) . * *, *$ significant at 0.05 and 0.10 by the test $\mathrm{t}$ of Student, respectively

The leaf index of chlorophyll "b" (LICb) decrease linearly with the increase of irrigation depths in both doses of $\mathrm{N}$ (Figure 4B).

\subsection{The Effect of the Irrigation Depths on the Water Use Efficiency}

The nitrogen use efficiency (NUE) was maximized (64.5 and $38.4 \mathrm{~kg} \mathrm{~kg}^{-1}$ ) under irrigation depths by 94 and $97 \%$ of $\mathrm{ET}_{\mathrm{c}}$ for $\mathrm{N}_{1}$ and $\mathrm{N}_{2}$, respectively. Furthermore, the increment of $100 \%$ of $\mathrm{N}$ dose increased NUE by only $70 \%$ (Figure 5A). 
A.

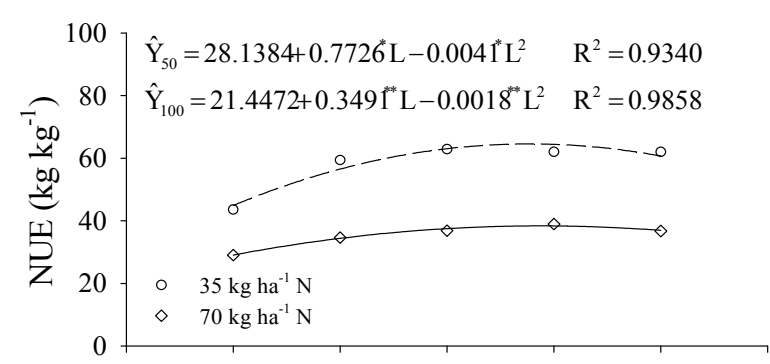

B.

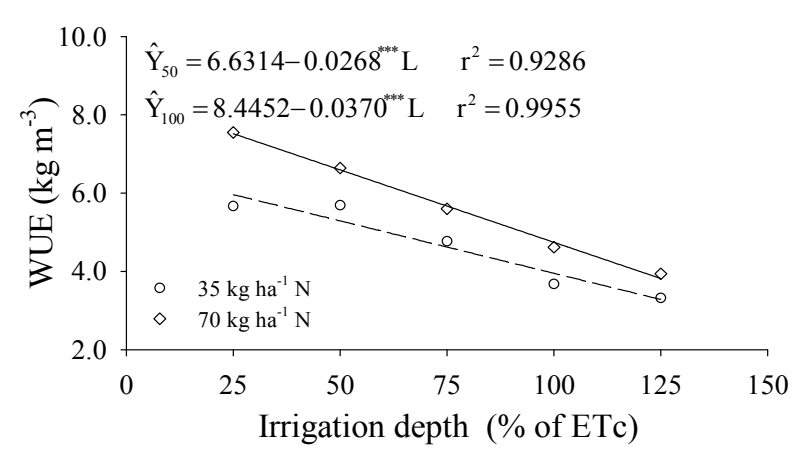

Figure 5. Nitrogen use efficiency (A) and water use efficiency (B) as a function of irrigation depths (\% of $\mathrm{ET}_{\mathrm{c}}$ ) and doses of nitrogen $\left(\mathrm{kg} \mathrm{ha}^{-1}\right) . * * * * *$ and $*$ significant at $0.01,0.05$ and 0.10 by the test $t$ of Student, respectively

The water use efficiency (WUE) decreases linearly with increment of irrigation depths. The WUE was maximum under $25 \%$ of $\mathrm{ET}_{\mathrm{c}}$, with values of 6.0 and $7.5 \mathrm{~kg} \mathrm{~m}^{-3}$ for $\mathrm{N}_{1}$ and $\mathrm{N}_{2}$, respectively (Figure $5 \mathrm{~B}$ ).

\section{Discussion}

In the cultivation of coriander is interesting for farmers maximize the reason AP/R. This reason provides evidence about the photoassimilates direction in the plants. Increment of water application was favorable to growing of leafs and stems than roots. Adequate soil moisture favorable to leaf transpiration and, as consequently, growing of leafs and stems (Hassan \& Ali, 2014). Contrarily, low soil moisture caused a plant morphological adaptation. The coriander reduce considerable the growing of aerial part for increase root development to found water (Hassan \& Ali, 2014). This information is crucial for irrigation management at the farmer level.

The $\mathrm{N}$ supply was determinant for the proportionality of the reason AP/R in rice (Ren et al., 2015) and wheat (Pietro-Souza et al., 2013). These authors observed considerable reducing of root development with $\mathrm{N}$ applying. For coriander, was observed growing of branches, leafs and umbels for adequate $\mathrm{N}$ applying (Angeli et al., 2016; Bhunia et al., 2009; Pooja \& Yadav, 2017). The N improves photosynthesis, rate of water uptake and root hydraulic conductance accompanied by aquaporin activity for rice crop (Ren et al., 2015).

Leaf area is correlated with biomass and seed production in coriander (Yeganehpoor et al., 2017). On leafs important physiological processes occur such as photosynthesis, respiration and transpiration. These processes are dependents of stomatal opening, which is closely correlated with soil moisture (Valença et al., 2018; Mu \& Fang, 2017). Undoubtedly, the condition of high soil water depletion is unfavorable to growing of coriander. Under low soil moisture, the transpiration reduce drastically, consequently decrease the assimilation of $\mathrm{CO}_{2}(\mathrm{Mu}$ \& Fang, 2017), resulting in low leaf area development.

Under moderate soil water deficit, maybe the coriander produce more chlorophyll "a" in order to maximize the efficiency of solar radiation absorption or it is possible that occurs the effect of concentration due to the lower growth observed for the leafs (Valença et al., 2018). However, under severe soil water deficit can increase the degradation of chlorophyll "a" (Valença et al., 2018) as observed in arugula (Freitas et al., 2017) and sweet potato (Delazari et al., 2018). Low chlorophyll "a" means decreasing of photosynthesis efficiency and consequently, less biomass accumulation. 
Satisfactory N supplying result in more leaf chlorophyll content (Sen et al., 2016). This occurs due increasing of enzymes production manly the Rubisco, which increase the demand of chlorophyll (Taiz \& Zaiguer, 2015).

The LAI was correlated negatively with LICb $\left(\mathrm{r}^{2}:-0.84, P: 0.027\right)$. Probably, occur the effect of concentration of chlorophyll "b" (Valença et al., 2018). Possibly, the chlorophyll " $b$ " is more resistant to degradation than chlorophyll "a" and can be an important index of hydric stress. However, contrarily to these results, in literature was observed decreasing in sugarcane (Gonçalves et al., 2017) and wheat (Al-Ghzawi et al., 2018) or not effect in Thymus daenensis (Bahreininejad et al., 2013) on chlorophyll "b" under soil hydric deficit.

Similar to leaf chlorophyll "a", adequate N supplying result in more leaf chlorophyll "b" content. Nitrogen being a major plant nutrient plays a major role in chlorophyll synthesis (Ren et al., 2015), photosynthetic activity (Ren et al., 2015) and crop growth (Angeli et al., 2016; Freitas et al., 2017).

The NUE is not proportional to $\mathrm{N}$ dose because the efficiency of $\mathrm{N}$ uptake decrease when increases the $\mathrm{N}$ supply (Bhunia et al., 2009) or because occurs loss by sublimation, denitrification, leaching (Mossavi, 2012). Moreover, high frequency of irrigation enhance the $\mathrm{N}$ uptake, which consequently improved the crop growth (Bhunia et al., 2009).

The lower WUE allied with increment of irrigation depths (Hassan \& Ali, 2014) could be due to a greater loss of water by evaporation than the corresponding increase of biomass (Allen et al., 1998). Higher $\mathrm{N}$ fertilization improve plant dry matter accumulation, manly due leaf grown (Angeli et al., 2016; Moosavi, 2012) increasing the WUE. Furthermore, high dose of $\mathrm{N}$ is linked with highest net return (Singh et al., 2018; Bhunia et al., 2009). In same crops it is possible used the regulated deficit irrigation for lower cost and high the WUE (Coelho et al., 2018). In this context, Angeli et al. (2016) suggest that products with high WUE should be paid differently, especially with the current situation of water available.

\section{Conclusion}

The treatment corresponding to $125 \%$ of ETc was the best irrigation depth, resulting in a greater relationship between the mass of the aerial part and mass of roots. The dose of $70 \mathrm{~kg} / \mathrm{ha}$ of nitrogen provided the best result. The leaf index of chlorophyll "a" and "b" are important indicators of hydric stress. The leaf index of chlorophyll "b" are negatively correlated with leaf area index. The leaf index of chlorophyll "b" decrease linearly with the increase of irrigation depths in both doses of nitrogen. The nitrogen use efficiency was maximized with high soil moisture conditions. The water use efficiency decreases linearly with increasing of irrigation depth. Nitrogen supply increase the water use efficiency.

\section{References}

Al-Ghzawi, A. L. A., Khalaf, Y. B., Al-Ajlouni, Z. I., Al-Quraan, N. A., Musallam, I., \& Hani, N. B. (2018). The Effect of Supplemental Irrigation on Canopy Temperature Depression, Chlorophyll Content, and Water Use Efficiency in Three Wheat (Triticum aestivum L. and T. durum Desf.) Varieties Grown in Dry Regions of Jordan. Agriculture, 8, 67. https://doi.org/10.3390/agriculture8050067

Allen, R. G., Pereira, L. S., Raes, D., \& Smith, M. (1998). Crop evapotranspiration-Guidelines for computing crop water requirements (p. 333). Roma: FAO Irrigation and Drainage.

Andrade, V. P. M., Silva, J. A. B., Souza, J. S. C., Oliveira, F. F., \& Simões, W. L. (2017). Physiological characteristics of grapevine under irrigation and fertilization management. Pesquisa Agropecuária Tropical, 47, 390-398. https://doi.org/10.1590/1983-40632017v4748640

Angeli, K. P., Delazari, F. T., Nick, C., Ferreira, M. G., \& Silva, D. J. H. (2016). Yield components and water use efficiency in coriander under irrigation and nitrogen fertilization. Revista Brasileira de Engenharia Agricola e Ambiental, 20, 415-420. https://doi.org/10.1590/1807-1929/agriambi.v20n5p415-420

Bahreininejad, B., Razmjou, J., \& Mirza, M. (2013). Influence of water stress on morpho-physiological and phytochemical traits in Thymus daenensis. International Journal of Plant Production, 7, 151-166

Bhunia, S. R., Ratnoo, S. D., \& Kumawat, S. M. (2011). Effect of irrigation and nitrogen on water use, moisture extraction pattern, nitrogen uptake and yield of coriander (Coriandrum sativum L.) in North-Western irrigated plains of Rajasthan. Journal of Spices and Aromatic Crops, 18, 88-91.

Carruba, A. (2009). Nitrogen fertilisation in coriander (Coriandrum sativum L.): A review andmeta-analysis. Journal of the Science of Food and Agriculture, 89, 921-926. https://doi.org/10.1002/jsfa.3535

Coelho, A. P., Dalri, A. B., Landell, E. P., Fischer Filho, J. A., Libardi, L. G., Bettiol, J. V., Faria, R. T., \& Palaretti, L. F. (2018). Productivity, technological attributes and water use efficiency of sugarcane cultivars 
under regulated deficit irrigation. Journal of Agricultural Science, 10, 174-183. https://doi.org/10.5539/ jas.v10n 7 p 174

Delazari, F. T., Assis, I. R., Cabrera, D. F., Ferreira, M. G., Dias, L. E., Rueda, A., Zanuncio, J. C., \& Silva, D. J. (2018). Morpho-physiological characteristics by sweet potato cultivars as function of irrigation depth. Anais da Academia Brasileira de Ciências, 1, 1-9. https://doi.org/10.1590/0001-3765201820170687

Diwan, G., Bisen, B. P., \& Maida, P. (2018). Effect of nitrogen doses and row spacing on growth and seed yield of coriander (Coriandrum sativum L.). International Journal of Chemical Studies, 6, 2768-2772.

Drunasky, N., \& Struve, D. K. (2005). Quercus macrocarpa and Q. prinus physiological responses to drought stress and their potencial for urban forestry. Urban For. \& Urban Greed, 4, 13-22. https://doi.org/ 10.1016/j.ufug.2005.07.001

Freitas, E. M., Giovanelli, L. B., Delazari, F. T., Santos, M. L., Pereira, S. B., \& Silva, D. J. H. (2017). Arugula production as a function of irrigation depths and potassium fertilization. Revista Brasileira de Engenharia Agrícola e Ambiental, 21, 197-202. https://doi.org/10.1590/1807-1929/agriambi.v21n3p197-202

Gonçalves, I. Z., Barbosa, E. A. A., Santos, L. D. S., Nazário, A. A., Feitosa, D. R. C., Tuta, N. F., \& Matsura, E. E. (2017). Water relations and productivity of sugarcane irrigated with domestic wastewater by subsurface drip. Agricultural Water Management, 185, 105-115. https://doi.org/10.1016/j.agwat.2017.01.014

Hani, M. M., Hussein, S. A. A. H., Mursy, M. H., Ngezimana, W., \& Mudau, F. N. (2015). Yield and essential oil response in coriander to water stress and phosphorus fertilizer application. Journal of Essential Oil Bearing Plants, 18, 82-92. https://doi.org/10.1080/0972060X.2014.974080

Hassan, F. A. S., \& Ali, E. F. (2014). Impact of different water regimes based on class-A pan on growth, yield and oil content of Coriandrum sativum L. plant. Journal of the Saudi Society of Agricultural Sciences, 13, 155-161. https://doi.org/10.1016/j.jssas.2013.05.001

Jamali, M. M. (2013). Investigate the effect of drought stress and different amount of chemical fertilizers on some physiological characteristics of coriander (Coriandrum sativum L.). International journal of Agronomy and Plant Production, 2, 872-879.

Kumar, A., Singh, R., \& Chhillar, R. K. (2008). Influence of omitting irrigation and nitrogen levels on growth, yield and water use efficiency of coriander (Coriandrum sativum L.). Acta Agronomica Hungarica, 56, 69-74. https://doi.org/10.1556/AAgr.56.2008.1.7

Moniruzzaman, M., Rahman, M. M., Hossain, M. M., Karim, A. S., \& Khaliq, Q. A. (2013). Effect of irrigation on seed yield and yield attributes of coriander (Coriandrum sativum L.). Bulletin of the Institute of Tropical Agriculture, 36, 035-043. https://doi.org/10.11189/bita.36.035

Moosavi, S. G. (2012). Flower fertility, yield and agronomical nitrogen use efficiency of fennel as affected by irrigation and nitrogen fertilizer rates. Technical Journal of Engineering and Applied Sciences, 1, 101-106.

Mu, L., \& Fang, L. (2015). Effects of different mulching practices on the photosynthetic characteristics of hot pepper (Capsicum annuum L.) in a greenhouse in Northwest China. Acta Agriculturae Scandinavica, Section B-Soil \& Plant Science, 65, 735-746. https://doi.org/10.1080/09064710.2015.1056545

Oliveira, A. P., Paiva Sobrinho, S., Barbosa, J. K. A., Ramalho, C. I., \& Oliveira, A. L. P. (2003). Rendimento de coentro cultivado com doses crescentes de N. Horticultura Brasileira, 21, 81-83. https://doi.org/10.1590/ S0102-05362003000100017

Pietro-Souza, W., Bonfim-Silva, E. M., Schlichting, A. F., \& Silva, M. C. (2013). Desenvolvimento inicial de trigo sob doses de nitrogênio em Latossolo Vermelho de Cerrado. Revista Brasileira de Engenharia Agrícola e Ambiental, 17, 575-580. https://doi.org/10.1590/S1415-43662013000600001

Pooja, P. K., \& Yadav, H. (2017). Influence of different levels of nitrogen and phosphorus on seed yield and economics of coriander (Coriandrum sativum L.). Journal of Pharmacognosy and Phytochemistry, 6, 157-160.

Ren, B., Wang, M., Chen, Y., Sun, G., Li, Y., Shen, Q., \& Guo, S. (2015). Water absorption is affected by the nitrogen supply to rice plants. Plant and Soil, 396, 397-410. https://doi.org/10.1007/s11104-015-2603-5

Santos, R. D., Lemos, R. D., Santos, H. D., Ker, J. C., Anjos, L. D., \& Shimizu, S. H. (2005). Manual de descrição e coleta de solo no campo (5th ed., p. 100). Viçosa: Sociedade Brasileira de Ciência do Solo. 
Schröder, J. J., Neeteson, J. J., Oenema, O., \& Struik, P. C. (2000). Does the crop or the soil indicate how to save nitrogen in maize production? Reviewing the state of the art. Field Crops Research, 66, 151-164. https://doi.org/10.1016/S0378-4290(00)00072-1

Sen, S., Smith, M. E., \& Setter, T. (2016). Effects of low nitrogen on chlorophyll content and dry matter accumulation in maiz. African Journal of Agricultural Research, 11, 1001-1007. https://doi.org/10.5897/ AJAR2015.9673

Singh, H., Panghal, V. P. S., \& Duhan, D. S. (2018). Irrigation and nutritional effect on growth and seed yield of coriander (Coriandrum sativum L.). Journal of Plant Nutrition, 41, 1705-1710. https://doi.org/10.1080/ 01904167.2018 .1459693

Taiz, L., Zeiger, E., Møller, I. M., \& Murphy, A. (2015). Plant physiology and development (p. 761). California: Sinauer Associates Incorporated.

Valença, D. D. C., Carvalho, D. F. D., Reinert, F., Azevedo, R. A., Pinho, C. F. D., \& Medici, L. O. (2018). Automatically controlled deficit irrigation of lettuce in "organic potponics". Scientia Agricola, 75, 52-59. https://doi.org/10.1590/1678-992x-2016-0331

Yeganehpoor, F., Zehtab-Salmasi, S., Shafagh-Kolvangh, J., Ghassemi-Golezani, K., \& Dastborhan, S. (2017). Assessment of Grain Yield Correlation with some Morphological and physiological traits, yield components and Essential oil in Coriander (Coriandrum sativum L.). Advances in Bioresearch, 8, 180-185. https://doi.org/10.15515/abr.0976-4585.8.3.180185

\section{Copyrights}

Copyright for this article is retained by the author(s), with first publication rights granted to the journal.

This is an open-access article distributed under the terms and conditions of the Creative Commons Attribution license (http://creativecommons.org/licenses/by/4.0/). 